\title{
A ROUTINE FOR THE OPEN-HOUR-LAB
}

\author{
by' Martin E. Goltichalk
}

In a program which requires compulsory laboratory attendance using commercial tapes there is a need for additional material. The student, who hears a tape in a regular scheduled period does not wish to return on his own time and listen to it again. He probably has not mastered it but nevertheless he wants variety.

As a result a routine was developed which has promoted a better attitude toward open-lab attendance among the students. This involves a set pattern of five specific steps for a fifty minute or one hour period. During this exercise three things are rigidly enforced: first, the sentences must be no longer than eight to ten words and if they are they are revised; second, the five steps should remain in the same order throughout the exercise; and third, a space is provided for the student to perform in each step and the correct form is given after he has had an opportunity to respond himself. sentence:

The following is an example of this drill pattern for one German

1. "Der Mann gab dem Jungen ein Buch." Wiederholen Sie, bitte: "Der Mann gab dem Jungen ein Buch." . . . "Der Mann gab dem Jungen ein Buch."

2. Ubersetzen Sie: "Der Mann gab dem Jungen ein Buch." . . . "The man gave the boy a book."

3. Beantworten Sie diese Frage: "Wem gab der Mann ein Buch?" ... "Dem Jungen gab der Mann ein Buch."

4. Sagen Sie im negativen: "Der Mann gab dem Jungen ein Buch." . . . "Der Mann gab dem Jungen kein Buch."

5. Stellen Sie eine Frage aus: "Der Mann gab dem Jungen ein Buch." . . . "Gab der Mann dem Jungen ein Buch?" tence:

The following is an example of this routine for one French sen-

1. "Il finit son travail a dix heures." Répétez la phrase, s'il vous plat: "Il finit son travail a dix heures." ... "Il finit son travail a dix heures."

2. Tradduisez: "Il finit son travail a dix heures." . . " He is finishing his work at ten o'clock."

3. Répondez a la question suivante: "A quelle heure finit-il son travail?". .. "Il finit son travail a dix heures." 
4. Dites la phrase au négatif: "Il finit son travail a dix heures." ..."Il finit pas son travail a dix heures."

5. Posez une question sur la phrase suivante: "Il finit son travail a dix heures." ... "Finit-il son travail a dix heures?"

The following is an example of this format for one sentence for English as a foreign language:

1. "We escape the dirty and crowded cities." Repeat, please: "We escape the dirty and crowded cities." . . . "We escape the dirty and crowded cities."

2. Answer this question: "What do we escape?" . . "We escape the dirty and crowded cities."

3. Give the sentence in the negative using the progressive verb form: "We are not escaping the dirty and crowded cities." . . . "We are not escaping the dirty crowded cities."

4. Make a question from the sentence using the emphatic verb form: "We escape the dirty and crowded cities." . . . "Do we escape the dirty and crowded cities?"

5. Change the subject to the third person singular using "he": "We escape the dirty and crowded cities." ... "He escapes the dirty and crowded cities."

At this time this technique has not been used for any other languages. However, it could be used for other languages with minor changes in the routine.

Changes can be implemented from time to time in the routine especially in steps three and five. For example, if the original sentence is negative an affirmative response can be demanded. Or a tense change can be made in step five.

By using this routine about thirty sentences can be covered in one hour. A one-hour tape will therefore be sufficient for two to four separate meetings, since the students do not mind listening to the material again because of its flexible nature. If one 30-sentence tape is not sufficient another can be added. This requires a total of sixty sentences for the work of one week which usually equals one lesson or chapter in a textbook. This technique therefore serves as a means to learn, to review and to entertain. Because the student is able to do that which is required it also builds confidence.

It must be emphasized that this routine does not attempt to cover the entire tape program. It is insufficient to do this. It is merely a sup- 
plement to the entire program; therefore, it does not compete with the commercial tapes. As the thirty or sixty sentences are composed for the work of each week an effort is made to provide an opportunity for the student to speak the language, not to present all the material, i.e., not every grammar principle and all the words plus syntax. Therefore, as the sentences are selected it is attempted to summarize the work for a certain section or chapter. As a result frequently very few sentences appear exactly as they are in the textbook.

Up to this point as far as the format has been tested a definite increase in interest, i.e. motivation, has been noted. At first the students had to be strongly urged to go to the lab for this voluntary hour but then the picture changed. Since they have become acquainted with the routine they are going more than one hour per week. This of course is the purpose of the routine, i.e., to stimulate the student to use the language.

ABOUT THE AUTHOR:

Mr. Martin E. Gottschalk is an assistant professor of German and labatory supervisor at the Howard Payne College, Brownwood, Texas.

\section{MEMBERSHIP APPLICATION for 1968-1969}

Check whether this is a (....) Renewal or a (....) New Member

Name:

Or Title:

Name of (High School) (University):

Circle one of the above

Address to which Newsletter is to be sent:

Address :

City : State Zip Code :

(....) My school is paying the dues for NALLD membership; send INVOICE to:

Check for which type of membership you are applying :

(...) Regular Voting Member (USA 50 States)

(....) Regular Voting Member (Foreign \& Canadian)

(....) Regular Voting Member (Foreign desiring Air Mail)

(....) Student, Non-Voting Member

Membership runs from October to October. Please complete the above form, and return the ENTIRE SHEET to: 